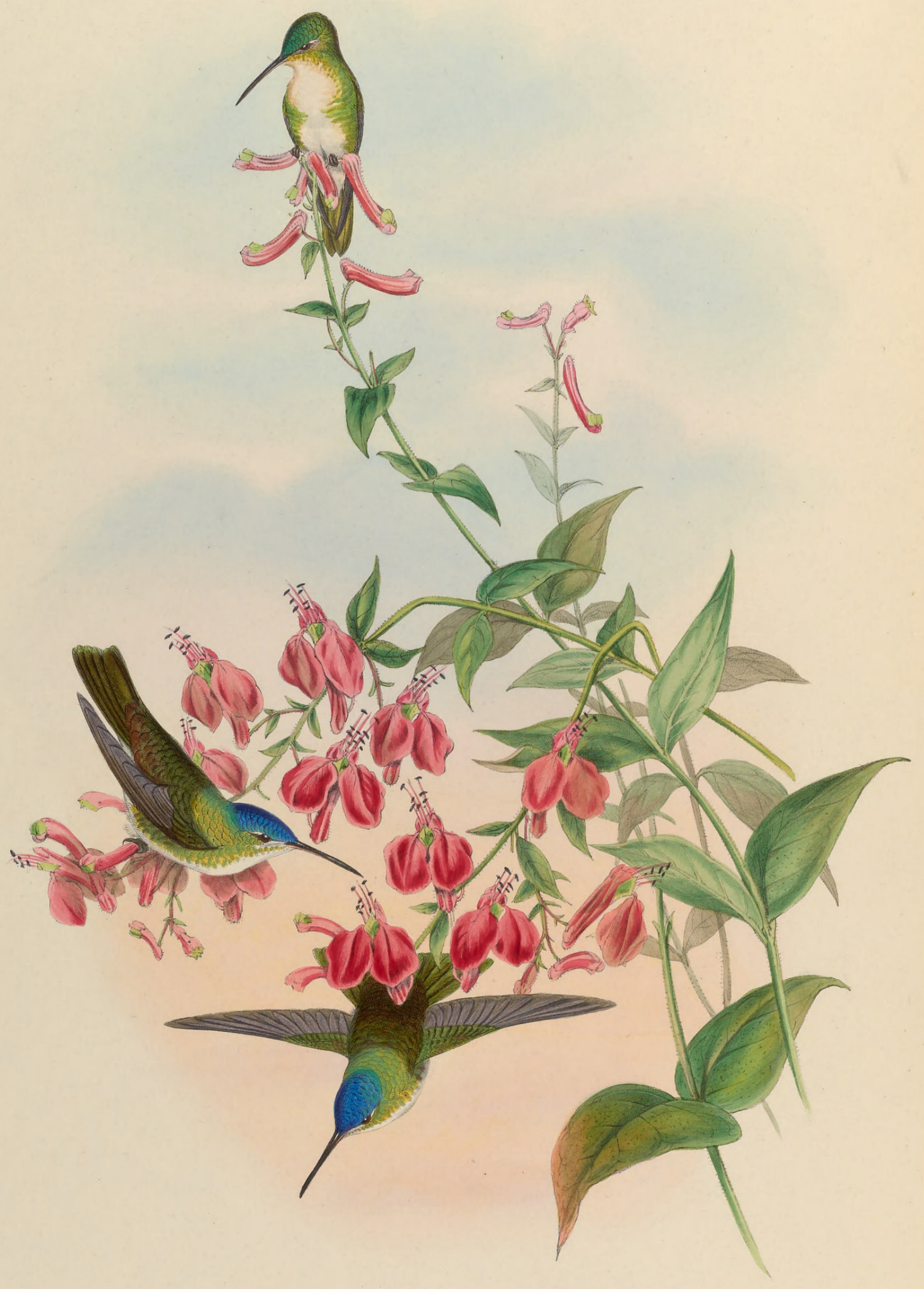




\section{CYANOMYIA FRANCIA.}

Francia's Azure-Crown.

Trochilus Francia, Bourc. Rev. Zool. 1846, p. 316.-Ib. Ann. Sci. Phys. \&c. de Lyon, 1843, p. 324 .

Uranomitra Francia, Reichenb. Auf. der Col., p. 10.

Cyanomyia francia, Bonap. Rev. et Mag. de Zool. 1854, p. 254.-Sclat. in Proc. of Zool. Soc., part xxiii. p. 141.

Polytmus Francia, Gray and Mitch. Gen. of Birds, vol. i., p. 109, Polytmus, sp. 87.

OF the five or six known species of the genus Cyanomyia the C. Francice may be regarded as the most beautiful, inasmuch as it is characterized by a far greater amount of glittering colour than any of its congeners, and by these glittering hues predominating on the sides and nape of the neck-parts not generally adorned with any fine colouring; there are, however, exceptions to all rules in the colouring of HummingBirds, and this is a case in point. The glittering of the parts referred to is so resplendent, that it is out of the power of any person, I believe, to portray them; hence art and device are in this instance at a nonplus. In the accompanying Plate a representation of these feathers is attempted with the ordinary media. If the reader can imagine the neck-plumes to be lit up with the most brilliant and glittering light possible, he may have some faint idea of their loveliness; it is only, however, in certain lights that these splendid colours appear; particular states of the atmosphere, or a certain condition of light, are requisite to see them in all their brilliancy. Viewed from behind, an obscure tint is alone visible; reverse the position, so that the rays of light fall upon the bird at a certain angle, and you become at once astonished at the difference.

I believe the female of this species has no brilliant colouring on the crown, - at least we have not yet received any example thus adorned; if, then, this conjecture be correct, the upper figure in the opposite Plate represents this sex.

M. Bourcier tells us that he has named this species in honour of a Mademoiselle Francia Bourcier, who is, I believe, his amiable daughter.

Crown of the head shining metallic blue; sides and nape of the neck glittering metallic light green ; upper surface and wing-coverts bronzy green, changing into coppery red on the lower part of the back and upper tail-coverts; wings purplish brown; tail bronze; throat, centre of the abdomen, and under tail-coverts snow-white; flanks bronzy green; upper mandible and tip of the lower one black; remainder of the under mandible fleshy ; feet dark brown.

The female or young male has the crown green ; only a trace of the coppery hue on the upper tail-coverts, and the lateral tail-feathers crossed by an obscure dark band.

The Plate represents two males and the female, or young male, of the natural size. The plant is the Cuphea cordata. 


\section{$2 \mathrm{BHL}$ Biodiversity Heritage Library}

Gould, John. 1860. "Cyanomyia franciæ, Francia's Azure-Crown. [PI. 287]." A monograph of the Trochilidae, or family of humming-birds 5, https://doi.org/10.5962/p.317096.

View This Item Online: https://www.biodiversitylibrary.org/item/108806

DOI: https://doi.org/10.5962/p.317096

Permalink: https://www.biodiversitylibrary.org/partpdf/317096

\section{Holding Institution}

Smithsonian Libraries

\section{Sponsored by}

Smithsonian Institution Libraries

\section{Copyright \& Reuse}

Copyright Status: NOT_IN_COPYRIGHT

This document was created from content at the Biodiversity Heritage Library, the world's largest open access digital library for biodiversity literature and archives. Visit BHL at https://www.biodiversitylibrary.org. 